\title{
IMPROVING STUDENT LEARNING ACTIVITIES THROUGH REALISTIC MATHEMATICS APPROACH
}

\author{
Mega Ratrisna Dyah Ayu Pamungkas ${ }^{\mathrm{a}}$, Abdul Taram ${ }^{\mathrm{b}}$ \\ Program Studi Pendidikan Matematika Universitas Ahmad Dahlan \\ Jalan Ring Road Selatan, Tamanan, Banguntapan, Bantul Yogyakarta \\ amegaratrisna27@gmail.com, btaramabdul@yahoo.com
}

\begin{abstract}
This research was carried out because of the activities of the eighth-grade students of SMP Muhammadiyah 2 Prambanan in the 2015/1016 school year in mathematics learning was still lacking. The purpose of this study is to increase the activity of students in mathematics learning by using the Realistic Mathematics Approach class VIII Even Semester SMP Muhammadiyah 2 Prambanan 2015/2016 academic year. This research is a classroom action research. The settings used are class VIII, amounting to 27 students. The study was conducted in 2 cycles, namely, cycle I and cycle II, each cycle consisted of 2 meetings. Cycle I and cycle II used the Realistic Mathematics Approach. Data collection techniques used were observation, interviews, documentation, and triangulation. Research instruments are observation sheets and interview guidelines. Instrument analysis uses content validity. The analysis used is descriptive qualitative. The results showed that learning using the Realistic Mathematics Approach can improve student activity in mathematics learning in class VIII SMP Muhammadiyah 2 Prambanan 2015/2016 academic year. This is evident from the results of observations of student activities in learning each cycle has increased, namely the average percentage of observation of student activities in the first cycle of 50,623\% which reached sufficient criteria, and in the second cycle increased to $61,960 \%$ which reached good criteria. The results of interviews with students showed a positive response to student learning activities.
\end{abstract}

Keywords: action research, Student Learning Activities, Realistic mathematics

\section{INTRODUCTION}

Mathematics is one of the important teaching materials and must be taught in the world of education in Indonesia. According to Lenner in Abdurrahman Mulyono (2003: 252), mathematics is a way to find answers; a way of using information, using knowledge of shapes and sizes, using knowledge about counting, and most importantly, thinking about oneself in seeing and using relationships. Therefore, students need to master mathematical concepts correctly and correctly. However, mathematics is a lesson that is less attractive to students. The majority of students avoid this lesson, the reason is that students consider that mathematics is a difficult lesson because many use formulas and learning seems boring. Mathematics learning outcomes obtained are usually lower than learning outcomes for other subjects. Less optimal mathematics learning outcomes are thought to be caused by several things including the lack of student learning activities in the learning process such as enthusiasm of students following learning, student interaction, group activities and lack of student participation in the discussion. Besides that it is also thought to be caused by the learning approach used by the teacher is still not optimal to improve the activity and student learning outcomes.

Approach is the way that the teacher takes when implementing learning so that the concepts presented can be adapted by students. According to Erman Suherman (2003: 6), there are 2 types of namely approaches are methodologies and material approaches.

According to Blumm and Niss in Sutarto Hadi (2005: 19), In the real world, a realistic mathematical approach (RMA) is used as a starting point for developing mathematical ideas and concepts. The real world is anything outside of mathematics, such as math subjects, or everyday life and the environment around us.

According to Troffers in Ariyadi Wijaya (2012: 21-23), there are five characteristics of the Realistic Mathematical Approach, namely (1) Use of context (2) Use of Models for progressive mathematical (3) Utilization of construction outcomes (4) Interactivity (5) Linkages 
The advantages of the Realistic Mathematics Approach according to Aris Shoimin (2014: 151152) are as follows (1) realistic mathematics learning provides clear understanding to students about daily life and general uses for humans, (2) realistic mathematical learning provides understanding clear to students that mathematics is a field of study that is constructed and developed by students themselves, not only by those who are called experts in the field, (3) Realistic mathematics learning provides clear understanding to students how to solve a problem or problem that does not have to single and not necessarily the same between one another (4) realistic mathematics learning provides a clear understanding of students in learning mathematics. Good or bad learning outcomes obtained by one of them are influenced by learning activities, where if learning activities are good then the results obtained will also be good. Hamalik Oemar (2011: 179), learning activities can be defined as various activities given to learning in teaching and learning situations. According to the Directorate of Guidance (2010: 57-58) about the technical guidelines for the preparation of affective assessment tools, student activities in mathematics learning can be seen from (1) student enthusiasm in participating in learning, (2) student and teacher interaction, (3) interaction between students, (4) group collaboration, (5) student activity in groups and (6) student participation in summarizing the results of the discussion. Therefore, to improve the activities and student learning outcomes of mathematics subjects, teachers must be able to create an optimal learning atmosphere by applying appropriate and enjoyable learning approaches. Cooperative learning models can be applied by a teacher in the process of learning mathematics. Realistic Mathematics learning approach which is expected to increase student learning activities because this approach is focused on the activity of students in the learning process so students can easily understand and present teaching material in the classroom.

The formulation of the problem in this study is Does mathematics learning using the Realistic Mathematics Approach increase mathematics learning activities in class VIII students of SMP Muhammadiyah 2 Prambanan in the 2015/2016 academic year?.

The purpose of this study is to improve the learning activities of mathematics with the Realistic Mathematics Approach can improve mathematics learning activities in class VIII SMP Muhammadiyah 2 Prambanan 2015/2016 academic year.

\section{METHODS}

This research is Classroom Action Research. The subjects of this study were grade VIII students of SMP Muhammadiyah 2 Prambanan in the 2015/2016 academic year which totaled 27 students. This research was conducted at SMP Muhammadiyah 2 Prambanan in the even semester 2015/2016 academic year. The object examined in this study was the implementation of processes and results obtained from realistic mathematical approaches to mathematics learning as an effort to improve the learning activities of class VIII students of SMP Muhammadiyah 2 Prambanan in the second semester of the 2015/2016 academic year.

The research procedure used in PTK consists of three cycles. Learning in the Cycle I, Cycle II and Cycle III stages using the NHT cooperative learning model then the researcher acts as a teacher. According to Suharsimi Arikunto, et al (2007: 16-20), the activities carried out in each cycle are as follows (1) planning, (2) implementation of actions, (3) observation and (4) reflection.

At this planning stage, the researcher prepares and prepares things as follows (1) plan for implementing learning (RPP) (2) observation sheet for student activities (3) student interview sheet

At the stage of implementation of the action, the activities carried out by the researcher were to implement the RPP that had been made, namely to conduct learning with the Realistic Mathematical Approach. The material discussed is about building a flat side cubes and beams with details as follows (1) in the first cycle the first meeting discusses nets, surface area and volume of cubes, the second meeting discusses surface area and volumes (2) in the second cycle of the meeting first discuss the surface area and volume of prisms and the second meeting discusses the surface area and volume of pyramid 
At this stage of observation, researchers are assisted by mathematics teacher class VIII acting as observers who observe all student learning activities when learning activities take place. At the stage of reflection, researchers and observers conduct a discussion to evaluate the teaching and learning process that has taken place and develop an action plan in the next cycle.

Data collection techniques used in this study are as follows (1) interviews were conducted on several students at the end of each cycle meeting, (2) observations were made to determine student learning activities during the learning process, (3) triangulation was interpreted as data collection techniques combining various existing data collection techniques and data sources (Sugiyono, 2015: 330). Triangulation is interpreted as a technique of collecting data that is combined from several existing data collection techniques. The purpose of triangulation is not to seek truth about some phenomena, but rather to increase the understanding of researchers about what has been found.

Analysis of the data used is descriptive analysis. The activity observation sheet was analyzed using the formula:

$$
P=\frac{n m}{N} \times 100 \%
$$

Information:

P : Percentage

nm : Number of items checked

$\mathrm{N}$ : Total number of items

The criteria for the P-value can be seen in the following table:

Table 1. Criteria for Value $P$

\begin{tabular}{|c|c|}
\hline Percentage $(\%)$ & Criteria \\
\hline $81 \% \leq \mathrm{NP} \leq 100 \%$ & Very Good \\
\hline $61 \% \leq \mathrm{NP}<80 \%$ & Good \\
\hline $41 \% \leq \mathrm{NP}<60 \%$ & Enough \\
\hline $21 \% \leq \mathrm{NP}<40 \%$ & Less \\
\hline $\mathrm{NP}<21 \%$ & Very Less \\
\hline
\end{tabular}

(Suharsimi Arikunto and Cepi Safruddin A.J, 2014:35)

The indicator of the success of this study is that student learning activities in mathematics learning increase, that is if student activities reach a minimum of good criteria, namely $>60 \%$.

\section{RESULTS AND DISCUSSION}

Learning that has been carried out thoroughly in the actions of cycle I and cycle II through a realistic mathematics learning approach shows that there is an increase in student learning activities on the subject of building a flat side space. Increased student learning activities can be seen in the following table:

Table 2. Percentage of Increase in Student Learning Activities at Each Indicator

\begin{tabular}{|c|l|c|c|l|}
\hline No & \multicolumn{1}{|c|}{ Indicator } & Cycle I & Cycle II & Information \\
\hline 1 & $\begin{array}{l}\text { Enthusiastic students in attending } \\
\text { the lesson }\end{array}$ & $54,63 \%$ & $72,037 \%$ & Increase \\
\hline 2 & Interaction with teachers & $50 \%$ & $61,111 \%$ & Increase \\
\hline 3 & Interaction between students & $47,703 \%$ & $60,185 \%$ & Increase \\
\hline 4 & Group collaboration & $45,389 \%$ & $62,963 \%$ & Increase \\
\hline 5 & Student activities in groups in & $51,407 \%$ & $61,574 \%$ & Increase \\
\hline 6 & $\begin{array}{l}\text { Student participation } \\
\text { summarizing learning outcomes. }\end{array}$ & $\mathbf{5 0 , 6 2 3 \%}$ & $\mathbf{6 1 , 9 6 \%}$ & Increase \\
\hline Average & $\mathbf{E n o u g h}$ & $\mathbf{G o o d}$ & Increase \\
\hline
\end{tabular}


For more details, it will be presented in the following graph:

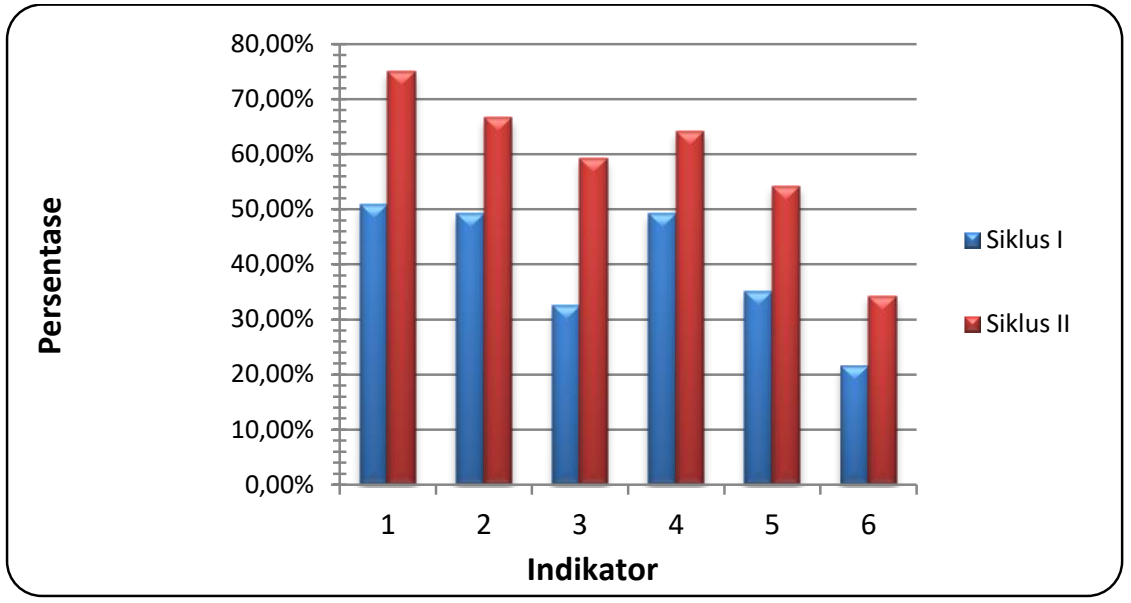

Picture 1. Graph of Increased Student Learning Activity for Each Indicator

Based on Table 2 shows that students as much as 50,623\% are active in learning activities. The number is not maximal because from the observation results there are still students who have not cooperated with each other in their groups, the interaction between students is still lacking as well as group discussions and class discussions to participate to conclude the results of the discussion are still lacking. This is due to the lack of teacher guidance in carrying out learning activities. After reflection of improvements in the teaching and learning process, in the second cycle, there was an increase in the percentage of student learning activities to $60.96 \%$ of students active in learning activities. This number meets the desired research criteria, which is above $60.00 \%$. The response of students and teachers in learning mathematics using a realistic mathematical approach is very good. This can be seen from the results of interviews with several students and class VIII mathematics teachers.

Based on the determination of the success of the research that has been determined previously, the research has succeeded. Provisions of success state that research is successful if student learning activities reach more than $60 \%$, while after doing the second cycle students get learning activities reaching $60.96 \%$. This means that student learning activities have exceeded the determination of the success of this study.

\section{CONCLUSION}

Based on the results of class action research it can be concluded that there is an increase in mathematics learning activities of class VIII students of Muhammadiyah 2 Prambanan Middle School in the 2015/2016 academic year. This can be seen from the indicators as follows:

1. There is an increase in student learning activities in the process of learning mathematics. Based on observational data there is an increase in the average percentage of student learning activities in each cycle which is equal to $50.6623 \%$ (sufficient) in the first cycle increased to $61.96 \%$ (good) in the second cycle

2. Mathematical learning using the Realistic Mathematics Approach gets a positive response from students, which means students can receive well and are interested in learning by using the Realistic Mathematics Approach This is evident from the results of interviews with students who showed learning to run smoothly and received a positive response.

\section{REFERENCES}

Aris Shoimin. 2014. 68 Model Pembelajaran Inovatif Dalam Kurikulum 2013. Yogyakarta : Ar-Ruzz Media.

Ariyadi Wijaya. 2012. Pendidikan Matematika Realistik Suatu Alternatif

Pendekatan Pembelajaran Matematika. Yogyakarta : Graha Ilmu 
Direktorat Pembinaan. 2010. Juknis Penyusunan Rancangan Penilaian Hasil Belajar SMA. Jakarta: Direktorat Pembinaan SMA.

Erman Suherman dkk. 2003. Strategi Pembelajaran Matematika Kontemporer. Bandung : JICA UPI Hamalik Oemar. 2011. Dasar-Dasar Pengembangan Kurikulum. Bandung : PT Remaja Rosdakarya Mulyono Abdurrahman. 2003. Pendidikan Bagi Anak Berkesulitan Belajar. Jakarta : Rineka Cipta.

Sugiyono. 2015. Metode Penelitian Pendidikan, Pendekatan Kuantitatif, Kualitatif dan R\&D. Bandung : Alfabeta.

Suharsimi Arikunto dan Cepi Safruddin A.J. 2009. Evaluasi Program Pendidikan. Jakarta : Bumi Aksara.

Suharsimi Arikunto, dkk. 2007. Penelitian Tindakan Kelas. Jakarta : Bumi Aksara. Supinah dan Agus. 2009. Strategi Pembelajaran Matematika Sekolah Dasar. Yogyakarta : PPPPTK

Sutarto Hadi.2005.Pendidikan Matematika Realistik dan Implementasinya. Banjarmasin : Tulip Banjarmasin. 